\title{
ПРАВОВІ ЗАСАДИ ЕКОЛОГІЧНОӤ БЕЗПЕКИ СІЛЬСЬКОГОСПОДАРСЬКОГО ВИРОБНИЦТВА
}

\author{
ХРИСТИНЧЕНКО Надія Петрівна - доктор юридичних наук, професор, \\ професор кафедри кримінального права і процесу, економічної безпеки та \\ правоохоронної діяльності Західноукраїнського національного університету \\ УДК 349.42 \\ DOI 10.32782/NP.2020.4.23
}

Стаття присвячена розробленню конщептуального підходу до розуміння правової природи екологічної безпеки сільськогосподарсъкого виробництва. У дослідженні наголошується на важливості иъого питання, $з$ огляду на те, що сучасне сільське господарство може бути досить небезпечним для навколишнього природного середовища. На теперішній час сільськогосподарсъке виробниитво не може розвиватись без широкого застосування пестищидів та агрохімікатів. Ця ситуаиія вимагає від держави забезпечити належний контроль за веденням сільсъкогосподарського виробництва та досягти балансу інтересів виробників та суспільства. Дотримання вимог екологічної безпеки сільсъкогосподарсъкого виробництва $\epsilon$ найважливішою умовою збереження родючості грунтів $i$ забезпечення якості продовольства, що споживається населенням.

Відзначаються недоліки, якими характеризуються нормативно-правові акти, що регламентують питання екологічной безпеки сільсъкогосподарсъкого виробництва. Розгляд найбільш значущих нормативно-правових актів показує, що в них відсутні конкретні иілі щодо екологізащй виробництва продовольства та оцінки агроекологічних ризиків. Крім того, відсутній акцент на екологічну ебективність; недостатніми є заходи, направлені на посилення контролю за інформачійною складовою продуктового виробництва.

Робиться висновок, що сфера екологічной безпеки сільсъкогосподарського виробництва характеризується досить об'ємним нормативно-правовим забезпеченням. Стверджується, що найближчим часом кількість нормативно-правових актів, що регулюють питання екологічної безпеки сільськогосподарсъкого виробниитва, буде збільшуватися. Цей момент обумовлюється, по-перше, потребою чіткого правового регулювання відносин в галузі екологічної безпеки сільськогосподарського виробництва $з$ метою збереження життя $i$ здоров'я населення, поліпшення якісного стану навколишнъого природного середовища; по-друге, необхідністю додаткового нормативно-правового регулювання відносин, що виникає у зв'язку з євроінтеграчійними прагненнями нашої держави та підписанням, у рамках иъого процесу, Угоди про асоціачію із Свропейсъким Союзом.

Ключові слова: екологічна безпека, сільсъкогосподарсъке виробниитво, захист довкілля, нормативно-правове забезпечення.

\section{Постановка проблеми}

На теперішній час Україна 6 аграрною державою, ключову роль в економіці якої відіграє сільське господарство. Не в останню чергу ця ситуація пов'язана із природними та кліматичними умовами, а також історичними обставинами, які дозволили сформувати потужне сільськогосподарське виробництво. Понад 70 \% всієї території нашої держави займають землі сільськогосподарського призначення, переважна більшість із яких - рілля.

Сучасне сільське господарство може бути досить небезпечним для навколишнього природного середовища. Зокрема, оскільки у сучасних реаліях воно не може розвиватись без широкого застосування пестицидів та аг- 
рохімікатів. Зазначена ситуація вимагає від держави забезпечити належний контроль за веденням сільськогосподарського виробництва та досягти балансу інтересів виробників та суспільства. Дотримання вимог екологічної безпеки сільськогосподарського виробництва є найважливішою умовою збереження родючості грунтів і забезпечення якості продовольства, що споживається населенням. Ця вимога знайшла своє відображення в чинному законодавстві, зокрема, згідно зі статтею 50 Конституції України, кожен має право на безпечне для життя і здоров'я довкілля. Природокористування має стати пріоритетним соціальним завданням держави, оскільки сприятливе навколишне природне середовище служить базисом здоров’я, праці, відпочинку та життя кожної окремо взятої людини.

У цей час, незважаючи на зусилия держави та суспільства щодо забезпечення необхідних вимог екологічної безпеки в сільськогосподарському виробництві, стан сільськогосподарських угідь, застосовувані технології виробництва i, як наслідок, якість продовольства i сільськогосподарської сировини знаходяться в зоні ризику. Науковцями неодноразово наголошувалось, що у вітчизняному землеробстві склався негативний баланс поживних речовин. Щорічний винос поживних речовин 3 грунту з урожаєм сільськогосподарських культур значно перевищує їх повернення з внесеними мінеральними, органічними добривами i рослинними рештками. Серед небезпечних негативних процесів, що впливають на земельні ресурси, відзначаються ерозія грунтів, ïх заболочування, засолення, опустелювання, підтоплення, дефляція грунтів, заростання сільськогосподарських угідь чагарником та інші негативні процеси, що ведуть до втрати родючості сільськогосподарських земель та їх виведення з господарського обороту.

За даними Державної служби України 3 питань геодезії, картографії та кадастру, деградація земель та опустелювання призводять до втрат біорізноманіття, погіршення стану або зникнення водних об'єктів, загострення проблем водозабезпечення населення i галузей економіки та, як наслідок, погіршення умов життя людей. Найбільш масштабними деградаційними процесами є водна та вітрова ерозія грунтів (близько 57 \% території країни), підтоплення земель (приблизно 12 \%), підкислення (майже $18 \%$ ), засолення та осолонцювання грунтів (більш як $6 \%$ ) [1].

Дослідженню окремих положень екологічної безпеки сільськогосподарського виробництва були присвячені праці таких учених, якВ. Андрейцев, 3. Беляева, А. Берлач, В. Гайворонський, В. Гуревський, А. Гетьман, В. Єрмоленко, В. Жушман, Р. Кірін, Н. Кравець, В. Курило, С. Марченко, Н. Тітова, В. Семчик, М. Козирь, Ю. Легеза, І. Ломакіна, О. Шкуратов,В. Янчук, А. Ярошенко та інші. Проте, з огляду на актуальність проблематики на теперішній період часу та останні законодавчі зміни, це питання потребує додаткового дослідження.

Метою цієі статті є розроблення концептуального підходу до розуміння правової природи екологічної безпеки сільськогосподарського виробництва.

\section{Виклад основного матеріалу}

На державному рівні екологічна орієнтованість виробництва дозволить забезпечити підвищення конкурентоспроможності вітчизняної економіки, шляхом поліпшення стану навколишнього природного середовища, підвищення якості та збільшення тривалості життя населення. Як правило, від екологічно орієнтованого виробництва на окремому підприємстві або галузі досить складно досягти негайного результату, у той же час, у масштабі району чи області такі переваги більш очевидні, навіть якщо вони не завжди відразу знаходять чітку економічну оцінку.

Основним принципом екологічної безпеки сільськогосподарського виробництва полягає у необхідності дотримання ії вимог на всіх стадіях виробництва сільськогосподарської продукції. Відповідно, основні цілі держави при провадженні сільськогосподарської політики полягають, зокрема, у забезпеченні якості українських продовольчих товарів, збереженні та відтворенні використовуваних для потреб сільськогосподарського виробництва природних ресурсів.

Розвиток сільськогосподарського виробництва перманентно перебуває у фокусі зору вітчизняного законодавця. Так, заслуговує на увагу проєкт закону про розвиток сільського господарства та сільських територій у 2017 - 


\section{Екологічне право}

2022 рр. (інтегральне село), який спрямований на вдосконалення нормативно-правового регулювання досліджуваних правовідносин. У пояснювальній записці до цього проєкту закону зазначено, що, зважаючи на надзвичайно високий потенціал сільського господарства в Україні, унікальне поєднання природно-кліматичних умов та геостратегічного положення, наявність чорноземів, традицій в сфері землеробства, тваринництва, рослинництва, розвиток сільського господарства та сільських територій повинен стати одним з головних пріоритетів держави [2].

На нашу думку, на додаток до природних причин, ключовою причиною, що призводять до погіршення родючості земель, є відсутність у власників землі стимулів до раціонального використання земель. Крім того, це положення посилюється тією обставиною, що ведення сільського господарства здійснюється в умовах малоефективного державного і громадського контролю за якістю сільськогосподарських земель.

Концептуально-програмна і законодавча основа у сфері забезпечення екологічної безпеки сільськогосподарського виробництва досить вагома і різноманітна. Визначенні «екологічна безпека» закріплено в законі України «Про охорону навколишнього природного середовища» від 25.06.1991 № 1264-XII. Так, згідно зі статтею 50 вищезазначеного закону, екологічна безпека $€$ таким станом навколишнього природного середовища, при якому забезпечується попередження погіршення екологічної обстановки та виникнення небезпеки для здоров'я людей. Екологічна безпека гарантується громадянам України здійсненням широкого комплексу взаємопов'язаних політичних, економічних, технічних, організаційних, державно-правових та інших заходів [3].

у сучасному українському законодавстві підкреслено взаємозв'язок екологічної безпеки та інших видів відносин у сфері безпеки держави і суспільства. У цьому аспекті, перш за все, слід вказати на норму частини 4 статті 3 закону України «Про національну безпеку України» від 21.06.2018 № 2469-VIII. Так, державна політика у сферах національної безпеки і оборони спрямовується на забезпечення воєнної, зовнішньополітичної, державної, економічної, інформаційної, екологічної безпеки, кібербезпеки України тощо [4].
Основним пріоритетом екологічної безпеки має стати забезпечення населення екологічно безпечними продуктами харчування, що включатиме в себе здійснення належного контролю за ввезенням, виробництвом і обігом продуктів харчування та їх компонентів. Також одним з основних напрямків державної політики в галузі екології та належного природокористування має стати впровадження систем облаштування сільськогосподарських земель і ведення сільського господарства, адаптованих до природних ландшафтів, розвиток екологічно чистих сільськогосподарських технологій, збереження і відновлення природної родючості грунтів на землях сільськогосподарського призначення.

Н. В. Кравець пропонує під екологічною безпекою у сфері сільськогосподарського виробництва розуміти такий стан захищеності життєвих інтересів людини і держави, навколишнього середовища в процесі аграрного виробництва, за якого забезпечуються збереження навколишнього середовища і його компонентів у безпечному для життя і здоров'я стані та виробництво якісної, екологічно безпечної сільськогосподарської продукції рослинного і тваринного походження. При цьому екологічна безпека в сфері сільськогосподарського виробництва $є$ невід'ємною складовою національної екологічної безпеки держави і співвідноситься з нею як часткове із загальним [5].

Наразі, серед завдань, що постають перед українським урядом, чільне місце відведено створенню ефективної системи державного регулювання та управління в галузі охорони навколишнього середовища та забезпечення екологічної безпеки, розвиток ринку екологічних товарів.

Тому, як зазначають науковці, існує необхідність у постійному вдосконаленні роботи органів державної влади шляхом системного моніторингу й аналізу їх роботи з метою виявлення випадків, коли певні функції є зайвими, спричиняють надмірну зарегульованість, що погіршує стан відповідного сектора економіки або ж, навпаки, недостатню врегульованість того чи іншого аспекту, а також щодо усунення суперечностей у питанні розподілу повноважень між різними суб’єктами регулювання [6].

У свою чергу, під суб'єктом, у широкому сенсі, розуміється: носій діяльності, що пізнає 
світ навколо себе та впливає на нього; людина або група осіб, культура, суспільство чи людство загалом, на відміну від того, що вивчається або змінюється внаслідок дій [7]. Як слушно зазначає О. І. Шкуратов, до основних суб'єктів організаційно-економічного забезпечення екологічної безпеки відносяться: державні органи влади, органи місцевого самоврядування та сільськогосподарські товаровиробники [8].

Заслуговує на увагу думка I. Аомакіної, що ефективність державно-правового регулювання сільського господарства можна визначити як результативну характеристику його дії, яка свідчить про здатність вирішувати відповідні соціально-правові проблеми. Ефективність державно-правового регулювання сільського господарства забезпечується такими факторами, як:

- ефективність законодавчого забезпечення;

- ефективність виконавчо-розпорядчої діяльності, що забезпечує конкретизацію норм закону на підзаконному рівні;

- ефективність діяльності щодо застосування положень закону спеціальними суб'єктами [9].

У цей період часу, в Україні фактично відсутня сучасна дієва екологічна політика, яка враховувала 6 нинішні реалії, спиралася на актуальний закордонний досвід і розглядала екологічний фактор як один з пріоритетів розвитку сільського господарства. Одна й головних проблем у цій сфері полягає в тому, що більшість українських підприємств, які займаються сільськогосподарським виробництвом досі не змінили свого ставлення до екології як до витратного компоненту. Вітчизняні підприємства все ще далекі від розуміння тих конкурентних переваг, які можуть бути отримані в результаті приєднання до цього нового і перспективного напрямку розвитку економіки.

В Україні прийнято цілу низку нормативно-правових актів, що регулюють відносини у сфері забезпечення екологічної безпеки сільськогосподарського виробництва. До таких відносять закони, технічні регламенти, постанови Кабінету Міністрів України, відомчі правові акти. Варто виділити найбільш значущі закони, що входять у цю систему, зокрема закон України «Про пестициди і агрохімікати» від 02.03.1995 № 86/95-ВР. Як зазначено в преамбулі, закон регулює правові відносини, пов’язані з державною реєстрацією, виробництвом, закупівлею, транспортуванням, зберіганням, торгівлею та безпечним для здоров'я людини і навколишнього природного середовища застосуванням пестицидів і агрохімікатів, визначає права і обов'язки підприємств, установ, організацій та громадян, а також повноваження органів виконавчої влади і посадових осіб у цій сфері [10].

Суттєве значення має закон України «Про державну підтримку сільського господарства України» від 24.06.2004 № 1877-IV. Цим законом визначено основи державної політики у бюджетній, кредитній, ціновій, регуляторній та інших сферах державного управління щодо стимулювання виробництва сільськогосподарської продукції та розвитку аграрного ринку, а також забезпечення продовольчої безпеки населення [11].

Варто відзначити певні недоліки, якими характеризуються нормативно-правові акти, що регламентують питання екологічної безпеки сільськогосподарського виробництва. Так, розгляд найбільш значущих нормативно-правових актів показує, що в них відсутні конкретні цілі щодо екологізації виробництва продовольства та оцінки агроекологічних ризиків. Крім того, відсутній акцент на екологічну ефективність; недостатніми видаються заходи направлені на посилення контролю за інформаційною складовою продуктового виробництва. У прийнятих технічних регламентах на сільськогосподарське виробництво відсутні цільові показники з екологічної безпеки.

\section{Висновки}

Проаналізувавши нормативно-правові акти та наукову юридичну літературу, варто констатувати, що сфера екологічної безпеки сільськогосподарського виробництва характеризується досить об'ємним нормативно-правовим забезпеченням. Також, дослідивши сучасний стан та перспективи розвитку зазначеного питання можемо стверджувати, що найближчим часом кількість нормативно-правових актів, що регулюють питання екологічної безпеки сільськогосподарського виробництва, буде збільшуватися. Цей момент обумовлюється, по-перше, потребою чіткого правового регулювання відносин у галузі екологічної безпеки сільськогосподарського виробництва $з$ метою 


\section{Екологічне право}

збереження життя і здоров'я населення, поліпшення якісного стану навколишнього природного середовища; по-друге, необхідністю додаткового нормативно-правового регулювання відносин, що виникає у зв’ язку з євроінтеграційними прагненнями нашої держави та підписанням, у рамках цього процесу, Угоди про асоціацію із Европейським Союзом. На нашу думку, чинні правові норми, що містяться у нормативних актах, доцільно об'єднати в комплексний правовий інститут екологічної безпеки сільськогосподарського виробництва, 3 метою поліпшення подальших наукових досліджень та правозастосовної практики.

\section{入ітература}

1. До Всесвітнього дня боротьби з деградацією та опустелюванням. URL: http://kharkivska. land.gov.ua/do-vsesvitnoho-dnia-borotby-zdehradatsiieiu-ta-opusteliuvanniam (дата звернення: 04.01.2020).

2. Проект Закону про розвиток сільського господарства та сільських територій в 2017-2022 pp. (інтегральне село). URL: http://w1.cl.rada.gov.ua/ pls/zweb2/webproc4_1?pf3511=59640 (дата звернення: 04.01.2020).

3. Про охорону навколишнього природного середовища: Закон України від 25.06.1991№ 1264-XII. Відомості Верховної Ради Украйни. 1991. № 41. Ст. 546.

4. Про Національну безпеку України: Закон України від 21.06.2018 № 2469-VIII. Відомості Верховної Ради Украӥни. 2018. № 31. Ст. 5.

5. Кравець Н. В. Екологізація аграрного виробництва як принцип аграрного права : автореф. дис. на здобуття наук. ступеня канд. юр. наук : спец. 12.00.06 - земельне право; аграрне право; екологічне право; природоресурсне право. Харків, 2015.19 с.

6. Ярошенко А. С. Світовий досвід та перспективні напрями реформування адміністративно-правового регулювання в галузі насінництва та розсадництва в Україні. Науковий вісник Херсонсъкого державного університету. Серія «Юридичні науки». 2015. Вип. 5. С. 100-103.

7. Костенко О. М. Адміністративно-правовий статус суб'єктів публічних закупівель в Україні. Вісник Запорізъкого національного університету. Юридичні науки. 2017. № 3. С. 98-105.

8. Шкуратов О. І. Методологічні основи формування системи екологічної безпеки в аграрному секторі економіки. Збалансоване природокористування. 2016. № 1. С. 153-158.

9. Аомакіна I Ю. Державно-правове регулювання сільського господарства України. Підприємниитво, господарство $і$ право. 2009. № 10.C. $138-140$.

10. Про пестициди i агрохімікати: Закон України від 02.03.1995 № 86/95-ВР. Відомості Верховної Ради Украйни. 1995. № 14. Ст. 91.

\section{SUMMARY}

The article is devoted to the development of a conceptual approach to understanding the legal nature of environmental safety of agricultural production. The study notes the importance of this issue, given that modern agriculture can be quite dangerous for the environment. Currently, agricultural production cannot develop without the widespread use of pesticides and agrochemicals. This situation requires the state to ensure proper control over the conduct of agricultural production and achieve a balance of interests of producers and society. Compliance with the requirements of environmental safety of agricultural production is the most important condition for maintaining soil fertility and ensuring the quality of food consumed by the population.

The article notes the shortcomings that characterize the regulatory legal acts regulating the environmental safety of agricultural production. Consideration of the most significant regulatory legal acts shows that they do not have specific goals for greening food production and assessing agroecological risks. In addition, there is no emphasis on environmental efficiency; measures aimed at strengthening control over the information component of food production are insufficient.

It is concluded that the sphere of environmental safety of agricultural production is characterized by a fairly extensive regulatory support. It is claimed that in the near future the number of regulatory legal acts regulating the environmental safety of agricultural production will increase. This point is determined, firstly, by the need for clear legal regulation of relations in the field of environmental safety of agricultural production in order to preserve the life and health of the population, improve the quality of the environment; secondly, the need for additional regulatory regulation of relations arising in connection with the European integration aspirations of our state and the signing of the association agreement with the European Union as part of this process.

Keywords: environmental safety, agricultural production, environmental protection, regulatory support.

11. Про державну підтримку сільського господарства України: Закон України від 24.06.2004 № 1877-IV. Відомості Верховної Ради Украӥни. 2004. № 49. Ст. 527. 